\title{
Stigmatized Blood in the Vatican Courts
}

\author{
Religious Response and Strategy
}

\author{
Leonardo Rossi
}

\section{Introduction: An Ambiguous Relationship}

You include Saint Pio [one of the most famous and much discussed stigmatics of the twentieth century, L.R.] among the most beautiful and luminous figures of your people. This humble Capuchin friar amazed the world with his life devoted to prayer and patient listening to his brothers, on whose sufferings he poured out the love of Christ as a balm. [...] he received special mystical gifts from above, which preceded the manifestation in his flesh of the signs of the Passion of Christ. ${ }^{1}$

With these words of approval, spoken during his pastoral visit to Pietrelcina and San Giovanni Rotondo on 17 March 2018, Pope Francis I celebrated the fiftieth anniversary of the death of Padre Pio (1968) and the centenary of the appearance of his permanent and visible stigmata (1918). ${ }^{2}$ As such, ecclesiastical approval of the mystical phenomenon was again confirmed. Indeed, in February 2016, on the occasion of the Jubilee of Mercy, the corpus incorruptus of the Capuchin friar had already been transported from the Apulian monastery to Rome, where it was worshipped in St Peter's Basilica by the Vatican clergy and thousands of believers. ${ }^{3}$ Given this special treatment, it seems quite evident

1 Pastoral Visit of the Holy Father Francis to Pietrelcina and to San Giovanni Rotondo on the occasion of the centenary of the apparition of the permanent stigmata and the fiftieth anniversary of the death of Saint Pio of Pietrelcina (17 March 2018): (Italian version) http://w2.vatican.va/content/francesco/it/speeches/2018/march/documents/papa -francesco_20180317_pietrelcina-fedeli.html; (English version) http://press.vatican.va/con tent/salastampa/en/bollettino/pubblico/2018/o3/17/180317a.html.

2 There are many biographies and scientific studies about the life of Padre Pio. Some of the most important are Da Ripabottoni, Padre Pio da Pietrelcina; Da Pobladura and Da Ripabottoni, Padre Pio da Pietrelcina, 4 Vols.; Di Flumeri, Le stigmate di Padre Pio; Di Flumeri, Padre Pio da Pietrelcina; Luzzatto, Padre Pio. Miracoli e politica nell'Italia del Novecento, English translation, Padre Pio: Miracles and Politics in a Secular Age.

3 The news travelled around the world and was reported in major newspapers such as L'Osservatore Romano, Avvenire, La Stampa, Repubblica, Corriere della Sera, Libero, Catholic 
that the Church officially supports the devotion to the stigmatized saint and uses his cult to spread Catholic messages and ideals of the societas Christi. For example, Padre Pio's traditionalist ideas about the family were taken up by the Catholic movement during the debate on LGBT rights in Italy, precisely during the Jubilee's period. ${ }^{4}$ If we link the Holy See's support of this modern case with that of the centuries-old devotion to the stigmatized saint par excellence, St Francis of Assisi (1182-1226), ${ }^{5}$ we might think that the Church favours all stigmatics. It could be argued, after all, that the stigmata have a devotional value because they are contextualized within the Catholic framework of the imitatio Christi and redemptive suffering. Is the Church's response to the bearers of the wounds of the Passion really so positive? How did the Vatican clergy regard other stigmatics?

The case of Gemma Galgani shows perfectly how the attitude of the Holy See towards holiness and stigmata is generally less explicit and more distrustful and reserved. Galgani (1878-1903), ${ }^{6}$ the first stigmatic who died and was proclaimed a saint in the twentieth century, was an Italian "stereotypical" stigmatic. She was a young lay woman who became famous during her life for her suffering, and as such a religious celebrity. ${ }^{7}$ Her visible phenomena and her status as a public persona created divisions among the diocesan clergy. On one side, there was the party of Mgr Volpi, ordinary confessor and supporter of the psycho-pathological thesis, who wanted to keep the signs secret. ${ }^{8}$ On the other side, there was friar Germano Ruoppolo, her last spiritual father and strenuous defender, who published extensively after her death, with the aim of conserving her memory and opening a canonical process. ${ }^{9}$ Despite

News Agency, Il Fatto Quotidiano, Catholic News Service, The New York Times, The Washington Post, Le Monde, Frankfurter Allgemeine Zeitung, Frankfurter Rundschau, La Vanguardia, De Standaard, De Morgen.

4 Margry, "Merchandising." In conjunction with the Jubilee and the transfer of the corpse of Padre Pio, the Italian parliament discussed matters concerning family law (homosexual civil unions). Catholic groups and the right, especially during Family Day on 30 January 2016, did not waste the opportunity to remember the teachings of the Capuchin saint regarding the traditional Catholic family, using him in a social and political way.

5 There is a recognized liturgical feast of the impression of his wounds (celebrated on 17 September).

6 Caffiero, "Gemma Galgani, santa;" Zoffoli, La povera Gemma; Dell'Addolorata, "Gemma Galgani (sainte);" Zoffoli, "Gemma Galgani, santa;" Bell and Mazzoni, The voices.

7 On stigmatics as religious celebrities, see Chapters 1, 3 and 4, on how to create religious fame, cult and commodity.

8 A study of the medical report and the diagnosis of hysteria advocated by Dr Pietro Pfanner can be found in Andreoli, "Un caso di santa isteria," 27-28.

9 Ruoppolo, Biografia di Gemma Galgani (1907) - in just six years, from 1907 to 1912, over 52,000 copies were printed - and Ruoppolo, Lettere ed estasi della Serva di Dio Gemma Galgani (1910). 
the media clamour and debate about her graces, after her death the Church paid only minimal attention to her stigmata, especially during the process of beatification (positive verdict in 1933) and canonization (1940). While Pius XI ratified the decree of the heroism of her virtues in the Acta Apostolicae Sedis (29 November 1931), ${ }^{10}$ he explicitly refrained from passing judgement on the preternatural origin of her phenomena," "upon which no decision is even made."12 From the pontiff's statement, we may indirectly grasp that at the time there was a heated debate about her graces, and in fact there were two images of Gemma that reinforced different profiles of sanctity: (1) the ecclesiastical and official image depicted her as a expiatory victim, a young virgin with a deep mystical life; and (2) the popular and devotional image was more interested in emphasizing the exceptional elements and the visible manifestations of her divine election (ecstasies and stigmata). The Vatican clergy chose the first model as it was more in keeping with the values of humility, obedience and resignation that the Church wanted to spread throughout Catholic society at the time. Moreover, avoiding consideration of the preternatural phenomena, it sheltered the saint from charges of hysteria, bigotry and fanaticism levelled by critics.

However, the reticence of the Church's leaders did not prevent the other profile proliferating in different circles, especially after the proclamation of her holiness. In fact, since 1940, the stigmata of Galgani have ceased to be a taboo topic, even for clergymen. We find this change apparent in an article by the Jesuit writer Domenico Mondrone (1897-1985), published in the journal La Civiltà Cattolica. ${ }^{13}$ Speaking about the papal prohibition mentioned above, he did not hesitate to interpret it as a strategy of the Holy See to contain the controversy regarding the "extraordinary facts, ecstasies, visions, words, stigmata, diabolic obsessions" that were attributed to Galgani. ${ }^{14}$ La Civiltà Cattolica

10 Villepelée, La follia della croce, 401.

11 In the papal bull mentioned, the exceptional phenomena attributed to Galgani (such as stigmata, ecstasy, prophecy, etc.) are designated by the word "preternatural." Since this chapter is concerned with the Vatican perception, we retain this term.

12 “...] feliciter elegit ut super heroicis virtutibus huius innocentis aeque ac poenitentis puellae suam mentem panderet, nullo tamen per praesens decretum (quod quidem numquam fieri solet) prolato iudicio de praeternaturalibus Servae Dei charismatibus." Acta apostolicae sedis, Commentarium Officiale 24 (1932), 54-57, 57: http://www.vatican .va/archive/aas/documents/AAS-24-1932-ocr.pdf.

13 On La Civiltà Cattolica, see De Rosa, "Alle origini della Civiltà Cattolica;" Dante, Storia della "Civiltà Cattolica" (1850-1891); De Rosa, La Civiltà Cattolica.

14 Mondrone, "Fulgori di santità e tenebre d'accecamento," Civ. Cat. 91, 2 (1940), 241-249. Previously, however, the attitude and language of the Jesuit fathers was much more hermetic. In 19o8, they wrote about the Servant of God: "Her sublime preternatural virtues 
has traditionally been the Jesuit magazine that followed the line of the Vatican curia. The reference to stigmata, therefore, can hardly be seen as a casual or personal thought of the author, but rather as a more positive acceptance of the phenomena by the Church. This trend was confirmed by the Passionist Fathers, who also seem to have adopted this change in perspective. They had been the advocates and financial sponsors of Galgani's process of canonization, and were also responsible for spreading the cult and producing commodities that promoted her (holy cards, images and relics).

As a Servant of God, Galgani was portrayed as a young woman in prayer (Fig. 7.1). After her beatification, some elements were added to display her virtues: lilies in her right hand, a symbol of virginal purity, while in her left hand she held a black Sacred Heart with the silver inscription "JESU XPI PASSIO," the emblem of the order (Fig. 7.2). In accordance with the ecclesiastical model, no visual element referring to physical stigmatization was present. After 1940, however, her holy cards became progressively embellished. In one image, Galgani is portrayed in an ecstatic state contemplating Christ Crucified, the symbol of martyrdom. On her left, at the bottom, an open book testifies to her mystical writing; while, at the top, angels, the Sacred Heard and the light over her head are proof of her canonized status. On her right, in the background, the "Sanctuary of Santa Gemma" has been added to emphasize that the saint belonged to the order of the Passionists. However, the main change we can see concerns her hand, on which the wounds of stigmatization are now visible (Fig. 7.3).

In other representations, her stigmata are more explicit. In one example, a ray of light coming from the Cross strikes and stigmatizes the body of the saint on the left, while an archangel sets the Crown of Thorns on her head (Fig. 7.4). Finally, as we can see in Figure 5, there is a complete transformation of the scenario. Gemma is represented as bedridden. From the crucifixion behind her, a divine light places the Crown of Thorns on her head, while her hands bleed. The scene is made more dramatic by the presence of a kneeling priest and a woman looking at her stigmatized hand (Fig. 7.5).

In comparison with the cases of Padre Pio, and St Francis in particular, whose miraculous stigmata were mentioned by the pontiffs in their bulls and encyclicals (as we will see later on), the ecclesiastical attitude towards Galgani and "prototypical" stigmatics was much more cautious, ambiguous and subject to change over time. The purpose of this chapter is therefore to focus on

and her extraordinary charisms were held only by a few Catholic saints". Anonymous, "Recensione: P. Germano di S. Stanislao, pass. - Biografia di Gemma Galgani vergine lucchese, $2^{\circ}$ ed., Roma, Artig.," Civ. Cat. 59 (1908), 2, 235. 
the Vatican response and measures taken towards stigmatics in the nineteenth and twentieth centuries. In the previous chapters, we examined how secular society received and perceived the bearers of the wounds of the Passion, by considering the views of lay visitors in particular. By doing so, however, we also had the opportunity to report on the role played by bishops and diocesan clergymen (primarily father confessors and spiritual guides). They had a key role in the promotion or censorship of stigmatics, both during their lifetime and afterwards. Despite differences related to national and local contexts, we have seen that in several European countries (Spain, France, Belgium, Germany and Italy) the bishops - as ordinari of their own dioceses - had the task of controlling, investigating and ultimately taking action on cases of alleged mysticism, lived holiness and stigmatization. In the ecclesiastical hierarchy, however, they occupied only the first and local level. At the highest level, the Holy See claimed greater and universal authority over the entire Catholic world.

To contextualize the Vatican response to stigmatics in the nineteenth and early twentieth centuries, it is necessary to analyse the broader framework, that is, how the Church considered the phenomenon of stigmata over a longer time frame. The first part of this chapter is therefore dedicated to the historical evolution of the relationship between the Holy See and stigmata, specifically reflecting on precise periods and themes: (1) the "invention" of stigmata in the Middle Ages; (2) the creation of congregations to control the phenomenon in the early modern era; and (3) the increase in cases in late modernity (c. 1800-1950). The second part, focusing on the nineteenth and twentieth centuries, will look at the methods and strategies used by two Vatican congregations to control stigmatics: (1) the Congregation for the Doctrine of the Faith (former Roman Inquisition, 1542-1908, and Holy Office, 1908-1965); and (2) the Congregation for the Causes of Saints (former Sacred Congregation of Rites, 1588-1969).

We address the Church's measures in order to contextualize the ecclesiastical framework in which stigmatics lived and operated. In some cases, the Church was able to influence the fame of the stigmatics, either creating, spreading or blocking it. This is especially true for Italy, which was unique both in terms of the number of stigmatics and the actions carried out by the Holy See. Of the 245 cases reported between the nineteenth and the first half of the twentieth centuries in the five countries studied, 87 are Italian. ${ }^{15}$ Of the three saints and fifteen blessed, the proportion of Italians is 2:3 and 11:15 respectively (we will discuss this in detail in the second section). Moreover, according to the material conserved in the Archive of the Congregation of the Doctrine of the Faith (again, we will see this below), it is clear that the Church was more

15 See bibliography in "Appendix." 
interested in intervening and condemning cases of stigmatization reported in Italy than in any other European state. This is not so surprising, as Italy was the country in which the stigmata of the first stigmatized saint were "invented."

The Vatican Perspective

\subsection{The Middle Ages and the "Invention" of Stigmata}

In the introduction to this chapter we have noted how the attitude of the Church has been decidedly cautious and reticent in taking a position on stigmata and their bearers. No ecclesiastical dogma has ever been expressed in this regard. Nevertheless, the Holy See has discussed and commented theologically on stigmata for centuries, drawing on both the Old and New Testaments. The term can be found in the Old Testament more than once, with the broad meaning of "sign."16 In the New Testament, the term is only mentioned in the famous letter of St Paul to the Galatians: "From now on let no one trouble me, for I bear in my body the marks of the Lord Jesus."17 For centuries, Church Fathers and theologians discussed the precise meaning that should be attributed to this phrase, in particular the visible or spiritual stigmatization of the Apostle of the Gentiles. The opinion widely shared by the clergy is that Paul was referring to the scars of martyrdom arising from the judicial-pagan persecution of the first Christian communities. As such, they are connected to the sacred wounds of the crucified Christ in a completely symbolic-allegorical way, and thus Paul is not considered the first stigmatic of the Christian era. ${ }^{18}$

In the first millennium of Christian history, stigmata were attributed exclusively to Christ. ${ }^{19}$ However, this changed when, in September 1224, a layman, Giovanni di Pietro di Bernardone (1181/2-1226) - better known as Francis of Assisi - received the visible marks of the Passion at La Verna. He was not merely a man, but destined to become one of the most controversial and famous characters marking the history of the Church and Europe itself after creating the Order of the Friars Minor. During his lifetime, however, the La Verna episode was entirely of secondary importance, as it occurred in secret, and only two years before his death. Francis never spoke about it, and certainly did not

\footnotetext{
16 Is. 44:5; Lv 19:28; Gen. 4:15; Ez. 9:4-6.

17 Galatians, 6:17 ("ego enim stigmata Domini Jesus in corpore meo porto").

18 Adnès, "Stigmates," 1213.

19 "[...] the medieval adoration of the holy Humanity remained foreign" ("l'adoration médiévale de la sainte Humanité lui est restée étrangère"), Lot-Borodine, "De l'absence de stigmates," 85 .
} 
leave any written record in which he mentioned or explained the event. The gap in the sources has led several historians (e.g. Sabatier and Renan) to question not only the divine nature of the wounds but also the occurrence of the event itself.

In this context, establishing historical evidence or siding with one party or another is not our goal. Whether Francis did or did not have the stigmata is irrelevant. Several scholars have already suggested that the Poverello of Assisi was not the first to have these marks on his body. Richard Trexler has argued that several ascetics before Francis had produced their own stigmata by flogging their bodies in penitential practice, as did the monks Dominic Loricatus (d. 106o) and Stephen of Obazine (1085-1159). ${ }^{20}$ Moreover, as early as the seventh century, there are reports of corpses appearing to exhibit the miraculous wounds. ${ }^{21}$ For all these cases, however, we cannot speak of stigmatics in the strict sense: at the time, the reference model had not yet been established. Before Francis, therefore, the stigmata had another meaning. The observation of corpses was a widespread practice in the early Christian community and had the function of "verifying" the presence of physical marks which proved the already reputed sanctity of the deceased. "Stigmata" simply meant the miraculous signs which the Lord had impressed on a corpse in order to certify the heroic nature of the living soul's virtues. ${ }^{22}$

In the case of the monks analysed by Trexler, however, their customs were part of a daily routine of discipline and self-flagellation. In the eleventh and twelfth centuries, a form of piety that was centred on the humanity of Christ and the redemptive value of suffering began to develop. From the Byzantine realm, the legend of the Inventio et Exaltatio crucis began to spread throughout Europe, involving an artistic and cultural shift from Christus triumphans to Christus patiens. In the devotional field, penitential practices such as temporary inedia, self-flagellation and mortification reflected the new perspective of salvific suffering, which had both individual and collective redemptive value. ${ }^{23}$

In the thirteenth century, the times were culturally and spiritually ripe for the account of the Franciscan friar, Thomas of Celano, who, in his Vita Prima $(1228-1229),{ }^{24}$ first described how Francis received the sacred stigmata. ${ }^{25}$

\footnotetext{
$20 \quad$ Trexler, "The Stigmatized Body," 463-497.

21 Muessing, "L'evoluzione della spiritualià," 31.

22 Muessig, Spiritualità delle stigmate, 31-32, n. 46.

23 Bonetti, Le stimate della Passione (1952), 128-142.

24 Thomas of Celano, "Vita Prima", and Thomas of Celano, "Vita secunda S. Francisci."

25 "Cernere mirabile erat in medio manuum et pedum ipsius non clavorum quidem puncturas, sed ipsos clavos ex ejus carne compositos, ferri retenta nigredine." Thomas of Celano, Vita Prima, 88.
} 
According to Celano, while meditating with his most faithful disciples on La Verna (the scenario recalls Jesus' retreat on the Mount of Olives), the Poverello of Assisi received the marks of the Passion on his flesh. The news was received as the "greatest miracle" in late medieval society, but also with reticence and suspicion. ${ }^{26}$ Gregory IX did not mention stigmata in the bull in which he decreed the canonization of the saint on 16 July 1228. However, between 1237 and 1291, nine papal bulls sanctioned the authenticity of La Verna's prodigy, ${ }^{27}$ with Gregory IX, Alexander IV and Nicholas III all defending the stigmata of the saint from attacks by medieval detractors. ${ }^{28}$

After the Vita Prima, the public debate and the canonization, the newly created but already powerful mendicant order commissioned Bonaventure of Bagnoregio (1217/21-1274) - cardinal, theologian and general minister of the Franciscans - to write the official biography of the holy founder. ${ }^{29} \mathrm{He}$ not only recounted the exemplary life of the Poverello, but de facto built the ecclesiastical image of St Francis as a stigmatized saint, indissolubly linking the holiness of Francis to the stigmata. The most evident sign of this exceptional transfiguration were the wounds that had opened on his flesh, reproducing the stigmata of the crucifixion on hands, feet, forehead and chest. ${ }^{30}$ They decreed Francis's divine election as alter Christus, the first in the history of Christianity. ${ }^{31}$

The central argument of this section, therefore, does not concern the historical authenticity of the stigmatic event but the cultural creation of this model and its impact on society at the time and subsequently. Without Francis, the popular cult of his stigmata and the theological disputation over them, it would be difficult to contextualize the cases that followed or place them under the category of "stigmatics." Starting from the thirteenth century, they had "the meaning of "mark, sign" in the Christian hagiography and mysticism, and are the signs of the wounds of Jesus imprinted in the body of a servant of God." ${ }^{32}$ As argued by Carolyn Muessig, in the construction of this definition, the

26 " [...] les stigmates ont été le plus grand des miracles - il y a toujours quelque témérité à classer les œuvres divines - au moins un miracles très grand et très avéré": Le Monnier, "Stigmates de Saint François," 1498.

28 Adnès, "Stigmates," 461. More recently, on the occasion of the seventh centenary anniversary of his stigmatization (1924), Pius XI decreed that this "wonder" was a historical fact proven by witnesses worthy of the faith, and therefore a certain and recognized act. Concerning the nature of the phenomenon, however, he added that questions were not allowed, because stigmata are not defined by canonical law or doctrine. Acta apostolicae sedis, Commentarium Officiale 16 (1924), 362-365.

29 Bonaventure of Bagnoregio, "Legenda Maior," Analecta Franciscana, 10 (1941), 557-652.

$30 \quad$ Muessig, "Signs of Salvation;" Benfatti, The five wounds of saint Francis, Chapter 11.

31 Frugoni, Francesco e l'invenzione delle stimmate, 150-182.

32 Alliney, "Stimmate," 11, 1342-1347, 1342. 
stigmata of St Francis "provide the key to interpreting the successive narratives of other people marked by the same wounds of Christ." ${ }^{33}$ In the first millennium of Christian history, stigmata were thus signs of the crucifixion of Christ, hence proof of his human nature (and not only divine). However, from the Middle Ages, their meaning moved beyond the rigid barrier of this Christocentric theology and were potentially attributable to other exceptional Christians as well: stigmatics were believed to be the privileged bearers of an exceptional charism, a gratia gratis data par excellence. ${ }^{34}$

At the end of the Middle Ages, a new type of stigmatization was "invented." Raymond of Capua, a Dominican friar and hagiographer, reporting the news of the invisible stigmata of St Catherine of Siena (1347-1380) in his Legenda maior. ${ }^{35}$ However, Catherine of Siena embodied a different model: female, third order and invisible stigmata. As demonstrated by Tamar Herzig, ${ }^{36}$ this news provoked heated discussion between the main mendicant orders. While the Franciscans exalted the stigmata of their founder as a unique miracle in the history of Christianity (therefore an exceptional and masculine attribute), the Dominicans proposed Catherine as the female counterpart of St Francis. ${ }^{37}$ The debate went on for centuries, and was discussed in theological reflections and papal decrees. The Church was very cautious about recognizing female charismatic authority. While Pius II did not mention the stigmatization of Catherine in the bull announcing her sanctification, the enthusiasm of the faithful gave rise to a form of "deviant devotion" to her, an unauthorized cult of the stigmata. ${ }^{38}$ Although the Franciscan pope Sixtus IV attempted to formally prohibit the veneration of the saint of Siena as a stigmatic through a series of papal acts, ${ }^{39}$ the cult continued to survive until its formal recognition in 1727.40 Catherine became the model for several women of the third Dominican order who emulated the life of the saint. Margaret of Hungary (1242-1271), Lucia Brocadelli (1476-1544), Domenica of Paradiso (1473-1553), and a group of

33 Muessig, Spiritualità delle stimmate, 21.

34 Tanquerey, Compendio di Teologia Ascetica, 1514-1515.

35 Raymond of Capua, "Vita sul profilo innovativo."

36 Herzig, "Stigmatized holy women."

37 Cohen, The Modulated Scream; and Trexler, The Stigmatized Body of Francis of Assisi, 463-477.

38 Herzig reports on the chronicle of Girolamo Albertucci de' Borselli, who testifies how, during a solemn procession in Bologna, her devotees venerated a painting of her with visible stigmata, Herzig, Stigmatized holy women, 156.

39 Ibidem.

40 In 1727, Benedict XIII decreed the feast of St Catherine's stigmata (1 April). Bartolomei Romagnoli, "La disputa sulle stigmate," 438. 
female "living saints" (or "sante vive") ${ }^{41}$ can be considered her spiritual daughters. While Francis was the first alter Christus, with Catherine and her emulators, "Christ was transformed into a virgin woman" who carried stigmata. ${ }^{42}$

After the invention of the models of stigmata in the forms of St Francis and Catherine of Siena, the phenomenon of stigmatization expanded on a large scale. Over the centuries, hundreds of cases have been reported. Those who carried the signs of the Passion and exhibited their prodigies to their contemporary community, gaining fame and popularity, were considered by historians and experts in the mystical field as stigmatics. The Vatican attitude towards them, however, was much more ambiguous and vague, so much so that they were not catalogued under the stigmatized label. The term appears rarely in the Vatican sources. Thus, it appears that by not using the word, the Church was hoping to deny or, in any case, minimize the phenomenon. While the Vatican sources speak of "stigmata," that is, of sacred wounds impressed on the body of Jesus, or an exceptional mystical gift granted to a few divinely elected souls, they do not speak of "stigmatics." From a theological point of view, this attitude emphasizes the wounds, atonement and suffering of the Passion, rather than the bearers themselves. They are, in fact, considered the tools by which the Lord communicates to the faithful.

In a practical sense, the Church could thereby avoid attributing excessive importance to potential "counter-powers." A reflection in Weberian terms may help to explain this point. ${ }^{43}$ While the Holy See is a centuries-old institution based on rational and traditional authority, stigmatics are, on the contrary, a potential living counter-power, endowed with irrational force. ${ }^{44}$ In cases in which the stigmatics showed an ambition for charismatic leadership, they benefited from spontaneous recognition and legitimization from below, as their stigmata were popularly considered to be the miraculous proof of their divine election. ${ }^{45}$

The attempt to minimize, hide, or not to speak about stigmata in relation to cases of presumed "living saints" does not in any way mean that the Church has ignored the issue. In the next section, we will see how the Vatican clergy

41 Zarri, Le sante vive.

42 "Ipsum Christum Ihesum in virgine quadam transformatum" as Cardinal Ippolito d'Este wrote. Reference reported by Herzig, Stigmatized holy women, 164. On the same topic: Gibson, "Could Christ Have Been Born a Woman?"

43 Weber, Economy.

44 Weber, Economy, 54-56, 241-246, 1163-1166.

45 On the "routinization" of charisma and the institutional process developed by the Church, see Stark, “The Routinization;" Lemmen, Max Weber's Sociology of Religion, ${ }^{135^{-152}}$ and Lüdecke, "Heiligsprechung." 
dealt with the stigmatics, especially from the sixteenth century onwards, when their numbers grew increasingly.

\subsection{The Early Modern Period: The Age of Control}

As we saw in the previous section, after the "invention" of the stigmata of St Francis and the codification of the female, invisible and less exceptional model of St Catherine, the number of stigmatics and "living saints" grew. Some of them gained fame and celebrity, and were considered worthy of worship by some. In contrast, the Vatican clergy saw them as a potential problem to be solved, and did so by controlling their devotional following and investigating their prodigies. Stigmata and visible mystical phenomena were elements to which the Church paid more attention, also being prepared to take more severe measures. In particular, in the early modern period there were two aspects that led the Roman curia to take action against aspiring saints: (1) their increasing number and (2) the Catholic reforms to holiness, cult and devotion.

At the turn of the fifteenth and sixteenth centuries, many "holy women" were reported in Italy. Through the divine graces they showed, they became religious celebrities in their time. They were called "sante vive" 46 by both the people and the sovereigns of the Italian states, with the latter even competing to host one of these charismatic women at their court. In addition to political prophecies and divine visions, one of the exceptional charismata of which they were equipped was the display of stigmata. Despite their success and fame during their lifetime, only some of these women were canonized by the Church. ${ }^{47}$ However, as demonstrated by Zarri, it is not officially recognized holiness that assists historians in understanding the popular perception of sanctity in a specific period. ${ }^{48}$ The exceptionality of the "canonized" and "living saints" (which sometimes coincide) of the early modern period indicate to us that at the time miraculous events and apocalyptic and prophetic announcements were abundant, being promulgated by a large number of people, especially women, both nuns and lay.

The Holy See was concerned about the high number of "living saints," their charismatic authority and their popular reputation. In particular, it wanted to supress the binomial vox populi, vox Dei. At the Council of Trent (1545-1563), the Catholic Church dogmatically decreed the validity of Catholic saints, clarifying

\footnotetext{
46 Zarri, Le sante vive, 11.

47 Veronica Neroni (1445-1497), Osanna Andreasi (1449-1505), Stefana Quinzani (14571530), Angelella Colomba Guadagnoli (1467-1501), Lucia Brocadelli (1476-1544), Caterina Mattei (1486-1547).

Zarri, Le sante vive, 11-13.
} 
those aspects of true and false sanctity, and the procedures for canonization. ${ }^{49}$ The goal was twofold: on the one hand, the decrees supported the cult of saints and their relics, which were being challenged by the Lutherans; and, on the other hand, they wished to marginalize the role of the faithful and the diocesan authorities in addressing the theme of holiness. ${ }^{50}$ For these reasons, two congregations were created for the control of the sacred and aspiring "living saints:" (1) the Roman Inquisition ${ }^{51}$ and (2) the Sacred Congregation for Rites. ${ }^{52}$

In 1542, Pope Paul III created the modern Roman Inquisition with the purpose of "judging all crimes against the faith throughout the entire Catholic world."53 Among the crimes that someone could be accused of by this tribunal was the category of "living saints," who could be found guilty of "affettata santità" (aspiring to holiness), that is, simulating holiness by demonstrating divine gifts that were in fact fraudulent attempts to obtain personal benefit. ${ }^{54}$ Faking divine gifts and charisms such as prophetic and miraculous abilities was considered to be a crime in canon law, inasmuch as it was against the principles

49 Waterworth, The canons (1848); Sacrosancti Concilii Tridentini, Canones e decreta, s. 25, 233-236.

50 Woodward, Making saints, 98-99.

$5^{1}$ From its foundation (1542) until 1908, it assumed the Latin name, Congregatio Romanae et Universalis Inquisitionis (in Italian, Sacra Congregazione della Romana e Universale Inquisizione, better known as Santa Inquisizione; in English, Supreme Sacred Congregation of the Roman and Universal Inquisition, or Roman Inquisition). From 1908 until 1965, it was called Sacra Congregatio Sancti Officii (in Italian, Sacra Congregazione del Sant'Uffizio, or Sant'Uffizio/Sant'Officio; in English, Supreme Sacred Congregation of the Holy Office, or Holy Office). In 1965, it took its current name, Congregatio pro Doctrina Fidei (in Italian, Congregazione per la Dottrina della Fede; in English, Congregation for the Doctrine of the Faith).

$5^{2}$ It was founded in 1588 and had the Latin name of Congregatio pro sacri ritibus et caeremoniis, or was simply known as Congregatio rituum (in Italian, Congregazione dei Riti; in English, Sacred Congregation of Rites). From 1969, it changed its name to Congregatio de causis Sanctorum (in Italian, Congregazione delle cause dei santi; in English, Congregation for the Causes of Saints).

53 Borromeo, "La congregazione cardinalizia dell'Inquizione," 328 . The programmatic manifesto, with the aims and objectives of the Vatican congregation, is contained in Paul III's bull incipit of Licet ab initio (1542): "Licet ab initio nostrae ad summi apostolatus apicem assumptionis id semper nobis cordi fixum institerit, uf fides catholica ubique floreret et augeretur, ac omnis haeretica pravitas a christifidelibus nostra diligentia procul pelleretur, necnon diabolica fraude seducti viam veritatis cognoscerent, et ad gremium et unitatem ecclesiae reducerentur; et si qui, animi preverisitate ducti, in eorum damnato propositio persisterent, ita plecterentur, ut eorum poena aliis transiret in exemplum." Gaude, Bullarum diplomatum et privilegiorum santorum romanorum pontificum taurinensis editio locupletior facta collectione novissima plurium brevium, epistolarum, decretorum actorumque S. Sedis a S. Leone Magnus usque ad praesens (186o), 344-346, 344.

54 Jacobson Schutte, "Finzione di santità," 6o1-604 and Jacobson Schutte, Aspiring Saints, passim. 
of true holiness established by the ecumenical Council of Trent. ${ }^{55}$ Among the preternatural phenomena, stigmata were considered one of the most dangerous, described as "fictions, hypocrisies, and artifices" operated by fraudsters, with the aim of creating inappropriate and cunning sanctity. ${ }^{56}$ In 1588 , the Congregatio pro sacri ritibus et caeremoniis was established by Pope Sixtus v, with the aim of regulating liturgical worship, the organization of pontifical ceremonies and, above all, the causes of canonization in the Catholic Church (the latter became the only object of interest in the seventeenth century). In the sixteenth century, attempts were already being made to oppose the opening of those processes of beatification in which the prodigious and charismatic element of the individual and his/her particular experience were exhorted, rather than their remarkable Christian virtues.

Ecclesiastical control led, on the one hand, to the negative labelling of visible mystical phenomena and, on the other, to the promotion of the cult of stigmatics whose profile perfectly followed the guidelines decreed by the Church. ${ }^{57}$ In the age of Catholic Reformation (sixteenth and seventeenth centuries), and later that of Enlightened Catholicism ${ }^{58}$ (eighteenth century), there were several privileged bearers, but only those who passed the test of a rigorous religious process were declared worthy of official veneration. ${ }^{59}$ If and how stigmata have influenced the cause of canonization, and how the cult of these saints created forms of emulation have yet to be investigated.

Despite the ecclesiastical measures of censorship and control, popular devotion to mystics carrying the stigmata was still alive in the seventeenth century. This piety perfectly accorded with the late Baroque mystic model. ${ }^{60}$ In the final decades of the century, the number of "living saints" and charismatic

55 Gotor, I beati del papa.

56 Biondi, "L'inordinata devozione," 320.

57 See, for example, the harsh condemnation of the Roman Inquisition in the work of Ioannes de Hibernia, entitled: "L'Exercitia, causae et effectus stigmatum à Satana impressorum" (ff. 241-242); and the anonymous volume, "De notis, et stigmatibus in corpore personarum de maleficio accusatarum repertis, utrum solae faciant indicium ad torturam et quibus indiciis concurrentibus e utrum sufficiant ad condemnationem" (ff. 243-244). ACDF, St.St. O 2 m 14, ff. 241-244.

$5^{8}$ On the term, "Enlightened Catholicism," see Manzoni, Il cattolicesimo illuminato.

59 Some of the most famous stigmatized saints lived or were canonized between the age of the (Counter)Reform and the baroque: Rita of Cascia (1381-1457: b. 1628, c. 190o); Catherine of Ricci (1522-1570: b. 1732, c. 1746); Mary Magdalene de' Pazzi (1566-1607: b. 1628, c. 1669); Charles of Sezze (1613-167o: b. 1882, c. 1959); Veronica Giuliani (166o-1727: b. 1804, c. 1831).

6o Caffiero, "Dall'esplosione mistica," 344 (an English version is available in Women and faith. Catholic religious life in Italy from late antiquity to the present, Cambridge-London, Harvard University Press, 1999). 
leaders increased again, as did the concern of the ecclesiastical leaders. The majority of clergymen criticized the belief in stigmata and mystical phenomena as irrational devotion and took their distance from them. This modern and rational current of Catholicism spread in the eighteenth century and shows the triumph of the enlightened clergy.

The greatest innovation of the eighteenth century in this field can be attributed to Cardinal Prospero Lambertini, the future Pope Benedict XIV, who worked on the monumental De servorum Dei beatificatione et beatorum canonizatione (1734-1738). ${ }^{61}$ In this study, he rationalized the procedure for the election of saints, redefining the criteria used by the Sacred Congregation of Rites. He decreed that miracles were essential, the conditio sine qua non for ascension to glory, and he anchored holiness in the more "objective" data of "heroic virtues." It was officially determined that the holy candidate had to prove they possessed heroic (i.e. at the maximum) levels of the three theological virtues (faith, hope and charity) and the four moral values (prudence, justice, fortitude and temperance). ${ }^{62}$ In what has been called "the first monumental history of canonized holiness in the modern age,"63 the Enlightenment clergyman opposed mystical-visionary religious manifestations - especially women's with a "regolata devozione" ("regulated devotion," i.e. a piety in line with the established canons). ${ }^{64}$ This represented a rational, ascetic and sober vision of faith. The hagiographic production, and therefore the texts selected to support the process of the canonization of the servants of God, was founded on philological research typical of the Acta Sanctorum of Bollandist friars and on the modern historical method introduced by Antonio Muratori. ${ }^{65}$ Predominantly, there was a basic refusal to accept legendary lives of saints based on tradition and hagiographies, in favour of primary and verified sources.

This revolutionary change did not condemn the stigmata in re ipsa, which indeed continued to be potentially accepted as gratia gratis data. ${ }^{66}$ However, along with ecstasies, visions and supernatural manifestations, they were definitively judged not to be proof of holiness. ${ }^{67}$ Instead of two explanations of

\footnotetext{
$61 \quad$ Lambertini, De Serovum Dei Beatificatione (1841), 3 vols.

62 Woodward, Making Saints, 393.

63 Gotor, Chiesa e santità, 120.

64 Rosa, "Prospero Lambertini."

65 Biondi, "Gli eretici modenesi nell'opera."

66 "Gratia vero gratis data est ipsa quoque donum supra naturam gratis a Deoconcessum, quod non facit per se gratum habentem illud, sed quod principaliter referitur ad aliorum utilitatem," Lambertini, De Serovum Dei, liber III, caput XLI, 5 O3.

67 Woodward, Making Saints, 163-164.
} 
such cases, there were now three, with mental illness (the famous hysteria) ${ }^{68}$ now added to the classical dichotomy between human or preternatural cause (divine or diabolic). Thus, as pointed out by Marina Caffiero, the anti-feminine mistrust moved by the erudite and rationalist fringe of clergymen led to an actual "block [of] suspect canonizations." ${ }^{69}$ This fundamental tendency seems to have also affected - and perhaps above all - the approved stigmatized saints, as in the case of Clare of Montefalco (1268-1308, whose sanctification was only approved by Leo XIII in 1881)..$^{70}$ Other processes of canonization were, however, carried forward and ancient questions resolved, ${ }^{71}$ but in no case was there an official recognition of the stigmata. On the contrary, on 27 April 1796, concerning the stigmata of Veronica Giuliani (166o-1727), Pope Pius VI declared that it was not up to the Church to rule on their nature, but left the question open to the faithful and scholars. ${ }^{72}$ This trend of suspicion, control and censorship continued to predominate in the Holy See, and became even more severe in the following centuries with the increase in the number of cases.

\subsection{The "Golden age" of Stigmatics: The Debate about Stigmata in the Nineteenth and Early Twentieth Centuries}

Although the cases of stigmatization appear to have been reported throughout the centuries, leading us to conceive that there was a continuation of the phenomenon without interruption, in some epochs their number was decidedly higher than in others. Significantly, rather than attesting to specific moments of political and socio-economic crisis, these peaks seem to be a response to a previous period of "persecution" of mysticism and "deviant devotion" to, or the emulation of, famous cases. ${ }^{73}$ As we have seen in the previous section, the strict measures taken in the epoch of the Counter Reformation did not prove sufficient to halt mystical cases in the fifteenth and sixteenth centuries. The

68 As early as 1729 , in the Vatican and diocesan investigation of the stigmatized Lucrezia Gambara (1704-1737), the local inquisitor and doctors used the term "pazza," that is, they considered her a young woman with a mental illness affected by hysteria. ACDF, Stanza Storica by St.St. f. $18 \mathrm{r}$ and Queriniana Library, Brescia (BsBCQ), Ms* L.II.13, Processo della causa di Lucrezia Gambara d'Alfianello, c. 124.

69 Caffiero, From the Late Baroque, 188.

70 Il processo di canonizzazione di Chiara da Montefalco, edited by Enrico Menestò, 434-436.

71 For example, the recognition in 1727 of the feast of the stigmatization of St Catherine (1 April) by Pope Benedict XIII.

72 de Pobladura, "Los procesos de beatificacion," 448 and Adnès, Stigmates, 1232.

73 See, for example, the Italian emulators or "spiritual followers," as they called themselves, of Gemma Galgani and Padre Pio, who were copiously reported on after public debate about their stigmata. Moreover, the element of influence played a central role in the creation of the "cloister". See Chapter 1. 
same occurred with the enlightened Catholic reforms and their attempt to "rationalize" popular piety.

An increasing number of stigmatics (as category) were recorded in the nineteenth and twentieth centuries. In the context of the revitalization of religion and a more tolerant position of the Church with respect to miracles, mysticism and popular devotion, hundreds of cases were reported across Europe. Because of their high number, and the fame and popularity they gained, we can label these centuries the "golden age" of stigmatics. ${ }^{74}$ While other scholars have already provided various interpretations and explanations for this growth in the phenomenon of stigmatization in late modernity, ${ }^{75}$ in this chapter our goal is to consider the relationship between the Vatican and stigmatics. Before analysing the ecclesiastical strategy used to deal with them in detail, we want to focus on two themes that played a central role in the Church's perception of stigmata: (1) the modern use and restoration of the cult of St Francis, and (2) the politicization of religion in the context of secularization.

At the beginning of the nineteenth century, an important event rekindled public interest in the saint with stigmata par excellence, and therefore in the phenomenon of stigmata tout court. In 1818, the remains of St Francis were found. The news resonated throughout Europe, with the Franciscan order and clerics making additional efforts to spread his cult, while historians and lay scholars also began to study his life. Karl von Hase (1856), ${ }^{76}$ Ernest Renan $(1866)^{77}$ and Paul Sabatier $(1893)^{78}$ all rewrote the life of St Francis from a historical-scientific perspective rather than taking an apologetic-hagiographic approach. As a result, his existence was divested of its mystical and exceptional phenomena, with Francis' stigmata interpreted in different ways: as illness, posthumous literary invention, or a scam operated within the Order. ${ }^{79}$ Starting with the Poverello of Assisi himself, doctors and scholars raised numerous doubts about the phenomena that were considered miraculous by the Church. The notion of his holiness was also challenged. The Holy See intervened in this cultural battle with the help of numerous Catholic writers and elements of the

\footnotetext{
74 See Chapter 1.

75 For a summary of different explanations and theories, see Van Osselaer, "Stigmatic women," 270-271.

76 von Hase, Franz von Assisi (1856).

77 Renan, "Saint François d'Assise, étude historique d'après le Dr. Karl Hase," Journal des Débats (August 20-21 1866) (repr. in Nouvelles études d'histoire religieuse (1884), 323-351). See also a modern edition, Renan, Oeuvres Complètes, ed. H. Psichari, vol. viI, 919-935.

78 Sabatier, Vie de S. François d'Assise (1893). Concerning Francis' stigmata, "Étude critique sur le stigmates et sur l'indulgence du 2 août: Les stigmates," 401-412. Frugoni, Francesco e l'invenzione delle stimmate.
} 
media. ${ }^{80}$ However, it also became even more cautious in accepting potentially mystical and preternatural elements, and in relation to St Francis only recognized his stigmata in the form of several liturgical celebrations (e.g. for the centenaries of his birth, stigmatization and death). The Poverello affair, analysed in a broader framework, granted the opportunity for modern society to reflect on the themes of sanctity and stigmata. ${ }^{81}$

The second element that played a key role in the evolution of stigmatics is linked to one of the master narratives of the religious and political history of the nineteenth century, namely secularization, ${ }^{82}$ and the conservative reaction of the Church..$^{83}$ In opposition to the secularization of politics and society, "from the end of the eighteenth century until Vatican Council II, the Church encouraged the miraculous as a way of defending the supernatural against the scepticism generated by the Enlightenment." 84 The Holy See sought to politicize the faith and above all popular devotional practices (Sacred Heart, Marian apparitions, the martyr pope), with the aim of re-converting society to Catholic values. ${ }^{85}$ Although the prophetic-apocalyptic messages of some visionaries were supported, ${ }^{86}$ as well as some charismatic figures, stigmata continued to remain taboo for the Holy See, to be hidden or suspected as a crime to be investigated. Of the three saints ${ }^{87}$ and fifteen blessed ${ }^{88}$ who had stigmata between the end of the eighteenth and the first half of the twentieth

8o See, for example, the articles that appeared in La Civiltà Cattolica at the end of the nineteenth century, which do not hesitate to denote non-Catholic historians as "Satanic," Anonymous, "Del Satanismo ai nostri tempi," Civ. Cat. 31, 3 (1880), 129-142.

81 Appelbaum, "St. Francis," and Bortolussi, Le stigmate.

82 On the difficult relationship between the Church, modern states and secularization in Italy, see Menozzi, Cristianesimo; Menozzi, La Chiesa cattolica, 34-55, 136-144; Menozzi, "La risposta alla secolarizzazione;" Traniello, Religione; Miccoli, "Chiesa."

83 Cox, "Secularization;" Cox, Master Narratives; Brown, The Secularization Decade, 29-46.

84 Woodward, Making Saints, 164.

85 On the conflict between Church and secularized society, especially in the Italian context, see Miccoli, "Chiesa e società;" and Traniello, Religione cattolica; Menozzi, Sacro Cuore; Menozzi, "Contro la secolarizzazione."

86 Curicque, Voix prophetiques (1872); Caffiero, "La fine del mondo."

87 Anna Maria Nicoletta Gallo (1775-1791: 1843), Gemma Galgani (1878-1903: 1940), Anna Schäffer (1882-1925: 2012), and Francesco Forgione alis Padre Pio (1887-1968: 2002).

88 Elisabetta Canori Mora (1774-1825: 1994), Anna Katharina Emmerick (1774-1824), Anna Maria Taigi (1769-1837: 1920), Gertrude Prosperi (1799-1847: 2011), Anna Rosa Gattorno (1831-1900: 2000), Maria Maddalena Starace (1845-1921: 2007), Teresa Adelaide Manetti (1846-1910: 1986), Maria Grazia Tarallo (1866-1912: 2006), María Josefa Alhama Valera (1893-1983: 2014), Elena Aiello (1895-1961: 2011), Itala Mela (1904-1957: 1976), María Pilar Izquierdo (19o6-1945: 2001), Lucila González María de Jésus (19o8-1936: 2007), and Maria Bolognesi (1924-1980: 2013). As noted above, these numbers refer to the five countries we studied. 
century, only four were popularly well known (both in the trial rooms and the public sphere) as bearers of the signs of the Lord's Passion. ${ }^{89}$ In some cases, this was due to the incidental occurrence of the phenomenon (occurring on only a few occasions and without great fame, or otherwise invisible) and the greater relevance of other charisms (charity to the poor and sick, heroic mothers, suffering victims, prophets and miracle workers). In other cases, however, the Holy See succeeded in its deliberate attempts to obscure and minimize the phenomenon during the lives of these people (controlling the Catholic mass media, not giving the imprimatur to suspicious articles or devotional images, or censoring them).

If, after their death, their fama sanctitatis remained in their communities, the cause of beatification - and ultimately even sanctification - was opened without any importance being given, and thus omitting any reference, to stigmata and phenomena that were considered embarrassing to the Church. Under the pontificates of John Paul II (1978-2005), Benedict XVI (2005-2013) and Francis I (2013-present), the prudence shown by the Church towards presumed charismatics and miracle workers has remained high. Cults and their leaders that had not yet been formally recognized, were now ignored, if not suspected or found fraudulent. ${ }^{90}$ However, other stigmatics were better received and found acceptance. This was the case with Padre Pio, who enjoyed great support and consideration under the pontificates of the popes mentioned above. The same can be said for Anna Katharina Emmerick (1774-1824), ${ }^{91}$ Anna Rosa Gattorno (1831-1900) $)^{92}$ and Maria Faustina Kowalska (1905-1938). ${ }^{93}$ In their cases, the Church recognized their stigmata (visible in Padre Pio's and Emmerick's cases, while invisible for the others) without, however, expressing a theological or dogmatic opinion about their nature, simply defining them as a "gift." 94 Should we consider this a sign of a new Vatican trend? We will return to this below.

In the history of the relationship between the Church and stigmata, the Vatican decisions taken in the dogmatic and theological context are of central

\footnotetext{
89 They are Padre Pio, Elena Aiello, Anna Katharina Emmerick and Maria Bolognesi.

90 Such as Angelo Giardino (1906-1979), Antonio Ruffini (1907-?), Erminia Brunetti (19141990), Natuzza Evolo (1924-2005) and Gigliola Ebe Giorgini (1933-).

91 http://www.vatican.va/news_services/liturgy/saints/ns_lit_doc_20041003_emmerick _it.html.

92 http://www.vatican.va/news_services/liturgy/saints/ns_lit_doc_20000409_beat-Gattorno _en.html.

93 http://www.vatican.va/news_services/liturgy/saints/ns_lit_doc_2000043o_faustina_it .html.

94 “[... the gift of hidden stigmata," see links in n. 92 and 93 above.
} 
importance; however, we cannot avoid broader reflection, which includes other agents involved in the matter. From the father confessor to the parish priest, from the spiritual director to the diocesan bishop, from the regional inquisitor to the local clergy, all had a role in the issue. ${ }^{95}$ The strategies they used can be divided into three main categories: support, condemnation or simply ignoring the issue. These different modi operandi could be adopted either during the life or after the death of a stigmatic. In the first case, they could, for example, benefit from the support of the spiritual father and local clergy, as well as the lay faithful; or, in contrast, be subjected to a trial at a diocesan (bishop's investigation) or central (by Holy Office) level. Alternatively, stigmatics might live their mystical experience in isolation, without attracting the attention of the religious authorities, perhaps spending their life within the walls of their own home or monastery.

After their death these dynamics could continue either in the same way or evolve in other directions. The memory of a stigmatic could fall into oblivion or, the reverse, retain or even gain in fame and popularity, prompting the faithful to ask the diocesan bishop to open a process of beatification. If their fama sanctitatis continued and a group of people or a religious order was willing to pay the costs and endure the long process iter, then the investigation could be opened. Divided into various and elaborate steps, this process could end in the official recognition of the sanctity of the stigmatic, or could be interrupted, thus blocking any formal legitimation.

These dual pathways, divided between the life and afterlife of stigmatics, was not only present at the diocesan ecclesiastic level, but it was even more elaborate in the Roman curia. In the early modern period, the Church had already developed systems of control through two formal congregations. In the nineteenth and especially in the twentieth century, both of them were reorganized, each taking a more severe approach to dealing with stigmatics.

\subsection{Stigmatics under Investigation during Their Lives}

It is not a coincidence that the statutes, procedures and composition of the Holy Office were profoundly transformed during an era that has been called a period of "overflowing mysticism." ${ }^{\text {" }}$ Above, we saw how the number of stig-

\footnotetext{
95 Van Osselaer, Smeyers and Rossi, "Fates and faiths intertwined."

96 The inquisitor, Donzella, used these terms when speaking about the case of the alleged stigmatic, Esterina Moriconini, in December 1924, Archive of the Congregation for the Doctrine of the Faith (ACDF), Rerum Variorum, 4, 482/1923, 54.
} 
matics increased during the nineteenth century and in the first part of the twentieth, when it reached its peak. While the previous pages reflected on the themes of the ecclesiastical debate about stigmata, in the following we consider how the Church, through the congregation of the Holy Office, sought to downplay and censure the fame and popularity gained by "living saints" who bore stigmata.

The reform season started with the Sapienti Consilio of 29 June 1908, ${ }^{97}$ through which the name of the congregation was changed from the Roman Inquisition to the Holy Office (Sant'Uffizio). ${ }^{98}$ In the same year, the Normae peculiares formalized the internal structure, the members who would take part and the procedures. ${ }^{99}$ The Lex et Ordo Supremae Sacrae Congregationis S. Officii of 1911 represents the most significant revision, although minor changes to the text were made until $1917 .{ }^{100}$ The pope was reconfirmed as the supreme summit of the restructured congregation, which retained the epithet of Suprema, as it was considered the most important among the Vatican congregations. In addition to the pope, a group of cardinals were selected as "general inquisitors," and there were a number of specialized figures who had different functions (councillors, secretaries, commissioners, consultants, tax lawyers, advocates for justice, notaries, etc.). ${ }^{101}$ The weekly agenda was rigorously planned and examined in special meetings called feriae. The consultors (external clergymen called on to inform the members of the congregation on specific cases) met on Monday (feria II ), the cardinals on Wednesday (feria IV), the particular congress (only the members of the Sant'Uffizio could participate) on Fridays or on Saturday (feria III), while the councillor went every Thursday to report and to seek approval from the Supreme Pontiff ( feria $V) .{ }^{102}$

The most significant change from the procedural point of view was a shift from a judicial process to an administrative one. Contrary to what one might think, this did not reflect a simple modernization due to changes in contemporary society (in which the Church had in fact lost all temporal authority and

97 Acta Sanctae Sedis, 1908, 41, 425-440.

98 Borromeo, La congregazione cardinalizia, 327; and Castelli, La Lex et ordo, 117. It was again modified in 1965 by Paul VI in the Sacred Congregation for the Doctrine of the Faith.

99 Acta Sanctae Sedis, 41, 1908, 707-712.

100 ACDF, Rerum Variorum 1916, 8, Dei delitti di competenza del Sant'Uffizio e delle irregolarità riservate al Sant'Officio. We find important information in this archival folder. If the most intense and decisive years of reform were those between 1911 and 1917, the internal modernization of the Congregation was already perceived as a problem at the beginning of the twentieth century. In the 1930s, the inquisitors continued to revise - albeit with minimal changes - the organization and functioning of the Holy Office.

101 Castelli, Padre Pio, 16-17.

102 Ibidem. 
therefore the right to intervene against lay citizens), but rather a reinforcement of inquisitorial power. Administrative practice, contrary to a penal approach, did not entail the opening of a formal process in which the offender was called to appear before the court accompanied by a lawyer, with witnesses appearing in his/her favour, and evidence presented to support his/her position. Instead, all trials ceased and the inquisitors decided on the mystical phenomena of the presumed bearer without allowing them to explain or defend themselves. In many cases, they did not even know the reasons why they were condemned by the Suprema, with the verdict unquestionable and the details secret. ${ }^{103}$

In the meetings held by the cardinals to discuss the changes to the congregation, the type of crimes to be investigated was one of the most important and recurrent issues. In particular, the crime of aspiration to holiness (Simulatio sanctitatis et peculiarumum divinorum charismatum) was presented and perceived as one of the most serious (in the sources it is called "delitto," i.e. murder). ${ }^{104}$ Investigating the exceptional graces of Ester Moriconi (1875-1937), Father Donzella - expressing the common ecclesiastical attitude - pointed out the need to halt the disturbing "overflowing mysticism" occurring in contemporary society. The increase in the number of stigmatics in the nineteenth century now alarmed the Vatican curia at the beginning of the twentieth century, forcing the clergy to take severe measures to contain the spread of unapproved cults.

If we consider how the policy was used over a hundred and fifty years, we can see important changes. Moreover, it is important to note that these changes were not sudden or dependent on specific decrees or acts. They were gradual and sometimes contradictory, based more often on the example of previous cases investigated rather than on regulations or general instructions about how to prosecute the crime. As deduced from the sources preserved in the Vatican archives, we can trace an evolution with three trends. Firstly, at the beginning of the nineteenth century, the Roman Inquisition - despite virtually claiming authority over the entire Catholic society - controlled the cases of mysticism and alleged holiness reported within the diocese of Rome and in the Papal States. The goal of the inquisitors was to punish specific suspect cases, especially charismatic religious women who claimed divine gifts with which they created a belief in their own living holiness. However, there does not seem have been a concern about the general diffusion of the phenomenon: it was not yet perceived as a problem.

103 Billanovich, "Una nuova invasione mistica," 43-45.

104 ACDF, Rerum Variorum, 1916, 8, Elenco dei delitti di competenza del Sant'Offizio, f. $4 r$. 
Secondly, while the situation changed progressively, by the middle of the century, and especially around the 1870s, the Church became aware of the dangers of the charismatic authority of "living saints," which could not always be routinized and officially recognized within the models of canonical sanctity. Thirdly, the reforms of the 1910s and the considerable increase in the number of cases marked an evolution in the modus operandi of the Holy Office, which completely centralized competences in relation to such cases (taking powers from local clergy and bishops). In the following, we will explain these trends through the examination of specific cases.

Although the Roman Inquisition had, since the sixteenth century, the task of combatting false sanctity throughout Catholic society in order to defend the canonized models of holiness, other authorities continued to play a fundamental role in the affair. As we have already mentioned, the bishops, the local clergy and tribunals of local inquisitions (47 throughout the Italian states) all had the right and duty to intervene. ${ }^{105}$ The Roman court functioned as a "common" local court, judging the cases of mystical aspirants reported within the confines of the Papal States. Only in certain cases would the Church deal with "living saints" beyond its own borders, either because they were particularly serious and difficult to judge or because the local courts asked for help. According to data collected by Jacobson Schutte, there were over 88 cases of presumed mysticism between 1580 and $175^{8}$ that underwent judicial process (38 men and 50 women), ${ }^{106}$ while Gottor refers to 120 cases. ${ }^{107}$ In the papers kept in the archive of the congregation, we do not see the number of stigmatics increase at the beginning of the nineteenth century. Following a centuries-old tradition, other powers continued to deal with "living saints." In the procedural documents, we find cases reported in the Papal States (such as Maria Agnese Firrao ${ }^{108}$ and Maria Bordoni), ${ }^{109}$ while other Italian cases were not examined within the Vatican. Significant examples of the latter are Maria Rosa Serra, Maria Domenica Lazzeri and the stigmatics of Tyrol in general: despite the international attention, the incredible number of pilgrims and the public and

\footnotetext{
105 Del Col, L'Inquisizione, 730-737.

106 Jacobson Schutte, Pretense of holiness in Italy, 95-96.

107 Gottor, Chiesa e santità, 113 .

108 ACDF, St. St. 5o B 6 a, Causa c. le monache e direttori del moanstero di S Ambrogio in Roma dette Riformate del terz'ordine di S Francesco.

109 ACDF, ( 4 i ), 1, Fano e Fossombrone n.16, Contra p. Danianum de Urbania de pretensibus spectantibus. Contra Mariam Tiberini viduam Bordoni aliosque complices. Contra Raphaelmem Mansaura laicum Philippinum. Contra Annam Marosini, n. 173, 1851, ff. $1 \mathrm{r}-35 \mathrm{O}$.
} 
media debate, the Vatican leaders did not feel the need to intervene, allowing the problem to be addressed by the competent local religious authorities.

If we exclude the cases of Anna Katharina Emmerick (1774-1824) $)^{110}$ and Louise Lateau (1850-1883), ${ }^{111}$ who were not really investigated but rather merely made known to the Vatican clergy, the first stigmatic who was examined by the Roman Inquisition after the union of the Kingdom of Italy and the end of the temporal power of the Church was Palma Matarrelli (1825-1888). ${ }^{112} \mathrm{Her}$ case is particularly important because it shows us that from the second half of the nineteenth century onwards, the Roman Inquisition claimed leadership, to the detriment of other authorities, in dealing with stigmatics, ecstatics and visionaries.

Matarrelli was a widow from Oria (a small town in southern Italy). Thus she was born in a territory that was not under Vatican control and the local bishop did not ask for any help from the Roman curia. At the age of 33 she received the stigmata (1858), and through the complicity of her spiritual fathers she became famous as "Beata Palma." Subsequently, Oria was overrun by the curious and the faithful, which prompted the public authorities to take action, with Matarrelli isolated in a private location where strangers could not visit her. Despite this, no official investigation was initiated by the local clergy, who continued to defend the divine nature of the graces of the charismatic woman.

News of the Apulian mystic only reached Rome in 1869, when her father confessor asked for the imprimatur of his work on an imminent publication dedicated to the "living saint." The inquisitors thus investigated her mystical phenomena by sending a clergyman to Oria and claiming superior authority over the local bishop. Matarrelli's case reveals how the attitude of the Holy Office changed in the second half of the nineteenth century, with the Church wishing to impose canonized cults and devotional models. This meant that "living saints" could not claim recognition of their charisms without the permission of the Holy See, while local religious authorities were also obliged to follow Vatican guidance. Of the 156 cases opened by the Holy Office to investigate the crime of simulated sanctity during this period, 89 concerned Italy and 67 involved other European nations. ${ }^{113}$ These figures show that (1) the Church

\footnotetext{
110 ACDF, so, St. St., C6 g, Manoscritto anonimo contenente la vita di Anna Caterina Emmerick.

111 ACDF, St. St. C 4 - f, g Pretesa stigmatizzata Luisa Lateau di Bois d'Haine.

112 Castelli, "Per una definizione;" Klaniczay, "The Stigmatized Italian Visionary."

113 Fassanelli, "Mentre vediamo che un falso misticismo," 90-91.
} 
was especially interested in controlling the faith in Italy and (2) the Holy Office worked as a national and international congregation beyond the Vatican boundaries. The goal of the Roman clergy was to claim the highest competence in matters of worship and holiness, not only virtually but also de facto.

The tendency towards centralization and bureaucratization of the Vatican offices was completed in the decade between 1908 and 1917. In the early part of the twentieth century, the Holy Office claimed complete control over investigations and the monitoring of stigmatics. As discussed above, these reforms gave the Holy Office more power, imposing its rules on bishops and diocesan clergymen. In the cases involving the religious (especially those who lived inside the Vatican City or in a convent protected by papal rules), rather than laypeople, its authority was basically unlimited. This is evident, for example, in the affair of Ester Moriconi (1875-1937), a stigmatized Augustinian nun. In her case, the cardinals decreed perpetual isolation in an asylum for the rest of her life.

However, and despite the great power it held through its prestige and the reforms of the 1910s, the Holy Office did not gain complete control over "living saints" and their cults. Other, including traditional, religious authorities, and above all the diocesan bishops, as well as other agents such as the faithful, the media and the scientific community, still claimed the right to intervene. In 1926, the Franciscan scientist and friar, Agostino Gemelli (1878-1959), sent a letter of complaint to the Holy Office about a young lay girl, Elena Aiello (1895-1961). Gemelli was not an official member of the Holy Office, but he was an important clergyman. He had decided to track down stigmatics and "living saints" personally, with the mission of scientifically demonstrating the nonmiraculous nature of their charismata. The inquisitors had begun investigating her case but had not given him any specific task, demonstrating they did not appreciate external influence and had not asked for his expertise.

Aiello had become famous for her stigmata, which were exceptionally bloody and sensational, first appearing in Lent 1923. Many laypeople, doctors and journalists subsequently arrived in her small village in the province of Cosenza (Calabria). Although the Holy Office was reticent and critical, the local clergy and the bishop supported Aiello, helping her found the Order of Minims of Our Lord Jesus Christ for the assistance of orphans. She had thus become a notorious religious celebrity. Endowed with charisms, such as stigmata and prophetic skills, venerated as a "living saint" by her own community, protected by the civil authorities due to her social and humanitarian commitment, Aiello could not be so easily condemned by the Holy Office. There is information on her in the Holy Office archive dated until 1939, after which the 
file is inaccessible. ${ }^{114}$ We can assume that her public status was so great that the inquisitors preferred to halt any investigation, giving her fame as a "living saint" the opportunity to spread.

Thus, in general, the Church sought to put an end to the alarming rise in stigmatics and their unapproved cults through reforms and strict measures. However, despite its commitment to the centralization of authority and skills, the Roman curia failed to achieve its desired goal, as popular devotion to "living saints" continued and in some cases this occurred despite condemnation by the Holy See. If their fama sanctitatis survived after their death, it was even possible that the Vatican would change its former negative attitude towards them, permitting their cult and sometimes providing official recognition of their sanctity.

\subsection{The Afterlife of Stigmatics: Damnatio Memoriae or Canonization?}

If the Aiello case shows the limits of the centralization of the Vatican congregations and the survival of other agents with power in relation to the subject, it is also useful when analysing the story of stigmatics in their afterlife. As mentioned above, while the Holy Office opened an investigation of Aiello, the support of the local clergy and the people never faltered. This allowed her to found and expand her institute, and to develop into what we might call a "heroine" of her city. After her death, her reputation for holiness was not forgotten, but instead was fuelled by hagiographies, other publications and supporters. The doubts and perplexities that had concerned the inquisitors in previous years vanished, and her beatification process was finally opened and subsequently concluded positively. On 14 September 2011, Pope Benedict XVI proclaimed her Blessed. ${ }^{115}$ How can someone who was accused of "affettata santità" become a saint? The following addresses the afterlife of stigmatics and how their reputation for holiness could continue, ultimately leading to their canonization. ${ }^{116}$

As noted above, after the reforms introduced by Urban VIII and BenedictXIV, sainthood was linked with Catholic virtues rather than exceptional and visible evidence. The latter were actually viewed with suspicion and reticence until modern changes to canon law on sanctity in 1917 (expressing the papal

\footnotetext{
114 ACDF, Res Disciplinares, Devotiones Variae, Devotiones Variae 1926, Cosenza. Aiello Elena, Affettata santità (ex monaca del Preziosissimo Sangue) e circa un certo ordine di suore, Dev.V. 1926 n.2, cc. 233.

115 The iter of her beatification can be consulted on the official website of her foundation: http://www.suoreminimedellapassione.it/iter-della-beatificazione/.

116 "The saint exists [...] within a series of concentric communities of family, neighbourhood, town, and religious order. [Sainthood is a, L.R.] social product constantly open to reinterpretation," Caciola, "Through a Glass," 303.
} 
authority on sainthood), 1969 (the creation of the modern Congregation for the Causes of Saints) and $1983 .{ }^{117}$ However, stigmata were not condemned per se and there remained a chance that they would be considered a divine gift. As pointed out by Oliver Bennett, the most recent reform, under the pontificate of John Paul II, made the procedures for beatification and canonization easier, ${ }^{118}$ so much so that there has been a surge in new saints, some of whom had stigmata during their life. Just as the Holy Office changed its practices at the beginning of the nineteenth century, so did the Congregation for the Cause of Saints, by turning from a juridical to an administrative-collegial system. ${ }^{119} \mathrm{In}$ accordance with these innovations, the process was no longer about defending the sanctity of the candidate against the objections of the Devil's Advocate, but involved a group of experts who were called the College of Relators, whose task it was to discuss the case. ${ }^{120}$

Five years after a candidate's death, a formal petition can be sent to the Vatican clergy, which decides whether or not to open the beatification process. The first phase takes place in the diocese where the future saint lived or worked. ${ }^{121}$ The task of the supporters and the local clergy is to collect documentation and testimonies. If they obtain permission from Rome, the diocesan bishop entrusts the task of writing a life (called a positio) of the Servant of God (in which the heroic virtues are described and tested) to a postulator, organizing the exhumation of the corpse and collecting medical evidence for the declaration of the miracle. Before 1983 , two miracles were required for nonmartyrs to become blessed, while at least two more were needed to become a saint (the number has now been reduced by half at each level). ${ }^{122}$ The work of the postulator, once completed, is sent to the Congregation for the Causes of Saints, which has the final task of discussing the suitability of the candidate and sending the final decrees to obtain the signature of the Supreme Pontiff. This change in the system, decreasing the number of miracles required, ${ }^{123}$ and the extension of the meaning of martyrdom (to include any victim persecuted

117 For the English and online version of the Divinus perfectionis magister (1983): http:// w2.vatican.va/content/john-paul-ii/en/apost_constitutions/documents/hf_jp-ii_apc _25011983_divinus-perfectionis-magister.html.

118 Bennett, "Strategic canonisation."

119 Bennett, "Strategic canonisation," 443.

120 The last test of the Vatican procedures for the canonization process was in 2001: http://www.vatican.va/news_services/press/documentazione/documents/avvenimenti/ canonizzazioni-beatificazioni_nota-procedura_it.html.

121 Ibidem.

122 Barro, McCleary, and McQuoid, "Economics of Sainthood," 197.

123 On the link between science and faith in the canonical process and the medical commission, see Woodward, Making Saints, 76, 194-201, 205, 208-209. 
in the name of faith), allowed John Paul II to create an unprecedented "factory of holiness." Under his pontificate, there were 482 canonizations and 1300 beatifications. In 27 years, he created more saints than any other pope in the history of the Church. ${ }^{124}$

In this procedural context, the Church was also called to express its position on the heroic virtues of candidates who had the stigmata. In some cases, even after death their fama sanctitatis survived, and a group of supporters or the monastic order to which the potential saint belonged demanded the opening of a process. ${ }^{125}$ If there were no convictions or reports filed within the Congregation for the Doctrine of the Faith (with the exception of the cases of Padre Pio and Elena Aiello), there were no major obstacles to the opening of an investigation. It was thus necessary to avoid charismatic gifts and preternatural phenomena, especially the stigmata, becoming the central element in the construction of a hagiographic profile. The Church maintained the position that there was no link between preternatural phenomena and holiness. Stigmata, prophecies and visions are not considered divine proof or a legitimizing element. Although in the nineteenth and twentieth centuries, the Holy See had a more positive attitude towards devotional forms and practices linked to popular cults, the "democratization" of religion and experiences of mystical feminine activities, the Church continued to contest the validity of stigmata and stigmatics. ${ }^{126}$ As already mentioned, of eighteen stigmatized saints and blessed in late modernity (c. 1800-1950), only four were known as stigmatics by both the religious authorities and lay society (at least on a large scale). The other fourteen were famous for other qualities or Catholic virtues, with the fact that they had stigmata remaining in the background. The examples below will make the situation clearer.

As explained in the introduction, the case of Gemma Galgani is emblematic and representative of the reticent and contradictory attitude of the Church towards stigmatics. The young mystic girl had shown exceptional charisms and the signs of the Passion on her body. These phenomena were widely discussed, especially among her spiritual guides, but right up until her canonization in 1940, they succeeded in keeping this from the public. The biographies, articles and devotional images of Galgani that appeared in the Catholic media reflected the model of heroic virgin and pious soul rather than privileged

\footnotetext{
124 Ciciliot "Heritage talks," 273.

125 They might be guided by religious orders (Capuchins as in the case of Padre Pio) or be a lay group (as in the case of Maria Domenica Lazzeri and Maria von Mörl).

126 Woodward, Marking Saints, 158-16o and 178-188.
} 
stigmatic. ${ }^{127}$ Thus, her stigmata were perceived as potentially dangerous during the investigations leading up to her canonization, elements to be hidden rather than emphasized. This attitude was not new for the Holy See. In earlier cases in the nineteenth century (e.g. Elisabetta Canori Mora and Anna Maria Taigi), ${ }^{128}$ during the beatification and sanctification process the Church had preferred to erase every aspect linking the candidate's profile of holiness with preternatural and exceptional phenomena. Pursuing this goal, their lives were rewritten and modified several times. In the halls of the Vatican congregation dedicated to the creation of saints, the word "stigmata" was seldom mentioned in the nineteenth and twentieth centuries. While it was used in the cases of Veronica Giuliani (166o-1727: beatified in 1804 and canonized in 1839) ${ }^{129}$ and Anna Maria Rosa Nicoletta Gallo (1715-1791: beatified in 1867), in both cases, the cardinals chose not to speak further about it and to suspend judgement of this mystical phenomenon. Therefore, they did not refer to it as additional proof of their sanctity. A century later, Pius XI stated that "no decision has been made" about the stigmata of Galgani, revealing ecclesiastical reticence in recognizing the phenomena as a divine gift and the bearers as saints for that reason alone. ${ }^{130}$

Only under the pontificate of John Paul II, the most prolific creator of saints in the history of the Church, do we see some signs of change. Firstly, he showed his appreciation for the friar of San Giovanni Rotondo while the latter was still alive, visiting Padre Pio for the first time in 1947, when he still was an unknown Polish clergyman. ${ }^{131}$ They maintained a correspondence, with Wojtyla asking Padre Pio for his prayers and intercession, although the friar was considered a fraud by other contemporary popes and large part of the Vatican clergy. Under the pontificate of the Polish pope, especially after his reforms of 1983, the canonical process for Padre Pio was extremely rapid. In the introduction to this chapter, we noted how the friar is today revered by the Church, but this was not always the case. In fact, he was investigated numerous times during his life,

127 We can further affirm this based on the titles of the books about her, di Stanislao, Lettere ed estasi della serva di Dio Gemma Galgani (Rome: Tipogr. Poliglotta dell'Ist. Pio IX, 1917); di Stanislao, Compendio della biografia della beata Gemma Galgani vergine Lucchese (Rome: Postulazione dei PP. Passionisti, 1933); Passionist Fathers, 1979. Estasi, diario, autobiografia, scritti vari di S. Gemma Galgani (Rome: Postulazione dei PP. Passionisti, 1979) [underlining for emphasis by author].

128 Van Osselaer, Rossi and Graus, "Virgin mothers," 175-176.

129 The memory of Giuliani is still present in the Vatican environment, as this papal General Audience of 2010 shows: http://w2.vatican.va/content/benedict-xvi/en/audiences/2010/ documents/hf_ben-xvi_aud_20101215.html.

130 Acta apostolicae sedis, Commentarium Officiale, 24 (1932), 54-57, 57.

131 Bennett, Strategic canonizations, 445. 
and he had been given heavy sentences (such as being prohibited from publicly celebrating the mass and confessing the faithful). ${ }^{132}$ Only after his death, and above all due to the support of the Polish pope, did his path to official sanctity appear unstoppable. It was so rapid that only 31 years after his death he was proclaimed blessed and three years later declared a saint.

If, in his case, it is apparent that the friendship and the bond that united the two clergymen played a leading role in the Vatican acceptance of the stigmata of Padre Pio, we can also see that there was a more general trend of acceptance. John Paul II in fact signed the decrees of beatification of seven stigmatics. ${ }^{133}$ Nevertheless, the stigmata continued to have a secondary function and they were not propaedeutic to the attainment of sanctity. The heroic virtues, according to canon law, remained the only essential condition.

At the same time, compared to the past, the stigmata no longer appear a taboo for saints-to-be. This trend has continued under the successive pontificates of Benedict XVI and Francis I, under which many causes of beatification that were opened during the era of John Paul in have been completed. Benedict XVI beatified four ${ }^{134}$ and canonized one bearer. ${ }^{135}$ While in the first five years of his reign, Pope Francis has signed the decrees for three stigmatized blessed. ${ }^{136}$ It will be interesting to follow developments in the Church's stance on stigmata in future canonization processes. ${ }^{137}$

\section{Conclusions}

In this chapter, we have seen that in its two millennia of history the Church has never officially recognized supernatural gifts in its dogmas or decrees, but has recognized a presumed divine nature in limited cases. Before St Francis, stigmata were only linked to Christ and were not considered a grace embodied by

\footnotetext{
132 Castelli, Padre Pio.

133 Teresa Adelaide Manetti (1986), Elisabetta Canori Mora (1994), Anna Schäffer (1999), Padre Pio (1999-2002), Anna Rosa Gattorno (2000), María Izquierdo (2001) and Anna Katherina Emmerick (2004).

134 Maria Grazia Tarallo (2006), Maria Maddalena Starace (2007), Elena Aiello (2011), Maria Luisa Geltrude Prosperi (2011).

135 Anna Schäffer (2012).

136 Maria Bolognesi (2013), María Josefa Alhama Valera (2014) and Itala Mela (2017).

137 Such as Luisa Piccarretta (1805-1947), Maria von Mörl (1812-1868), Maria Domenica Lazzeri (1815-1848), Angela Molari (1821-1887), Veronica Barone (1856-1878), Maria Concetta Pantusa (1894-1953) and Filomena Carnevale (1929-1959). (Focus on the five countries we studied.)
} 
Catholic saints and mystics. From the thirteenth century onwards, reaching its peak in the nineteenth and twentieth centuries, hundreds of stigmatics were reported across Europe, gaining in public attention. Some quickly fell into oblivion after a short moment of fame, while others became religious celebrities, charismatic leaders and "living (but rarely recognized) saints." Often, they had problems with religious authorities at various levels (from their confessors and spiritual guides to bishops and inquisitor cardinals), provoking strong debate between Vatican theologians and clergy.

Throughout the Middle Ages, stigmata generated discussion among the two main mendicant orders, the Franciscans and Dominicans, who claimed the mystic gift as an exclusive characteristic of their respective founders. In the early modern age, however, the stigmatic phenomenon spread beyond the purely religious context, involving laypeople and, above all, popular cult. Specific Vatican congregations were created to investigate living mystics, elaborating certain profiles of holiness. The contemporary age, despite historiographic theories of the secularization of political power and the rationalization of society, saw the phenomenon grow exponentially, reaching its peak between the end of nineteenth and the first half of the twentieth century. Moreover, it was not only the Vatican clergy that studied and investigated the stigmatics through the Holy Office and the Congregation for the Causes of Saints, as other actors also continued to have responsibilities and prerogatives (the faithful, fathers, confessors, bishops).

After disapproving of charismatic forms in the late eighteenth century and a battle against a new rise of mysticism in the first half of the twentieth century, since the pontificate of John Paul II, the Church seems to have become a little more open to cases of stigmatization. The exceptional sanctification of Padre Pio in 2002, the continued honours paid to him by Benedict XVI, and even today by Francis I, demonstrate not only the good fortune of the stigmatized friar, but a more indulgent acceptance of the stigmata and stigmatics, especially after their death. Nevertheless, the Vatican stance towards stigmatized "living saints" is still complicated and extremely cautious. ${ }^{138}$

However, as the case of Aiello showed, severe ecclesiastical opposition to and censorship of stigmatics can change after their death. As was the case for

138 Living stigmatics include Domenica Galelo (1950-), a Calabrian housewife; Elia Cataldo (1962-), who pretends to be friar and leads a sect of followers in Apulia, now under Vatican investigation; Caterina Bartolotta (1963-), a mystic and Marian visionary; Giorgio Bongiovanni (1963-), a Sicilian seer who became very famous in the US for his speeches, which combine Christian doctrine and theories about aliens; Myrna Nazzour (1964-), a mystic from Damascus. 
Galgani, their lives can be adapted and rewritten, in line with a more canonical profile of holiness. Thus, also the harshest judgements can turn into positive acceptance, just as Padre Pio developed from one of the most famous "psychiatric hospital mystics"139 to one of "the most beautiful and luminous figures" of Christianity. ${ }^{140}$

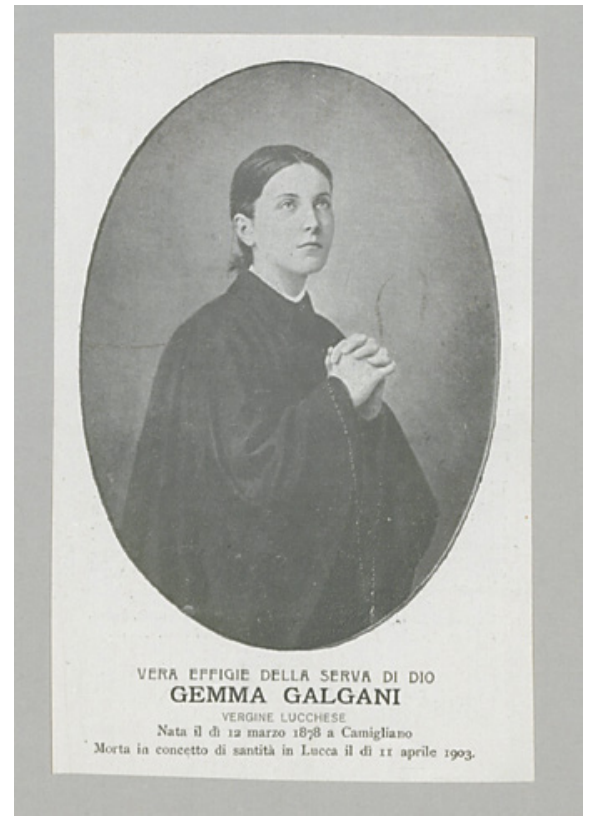

FIGURE 7.1

"Vera effigie della Serva di Dio Gemma Galgani" ANTWERP, RUUSBROEC INSTITUTE

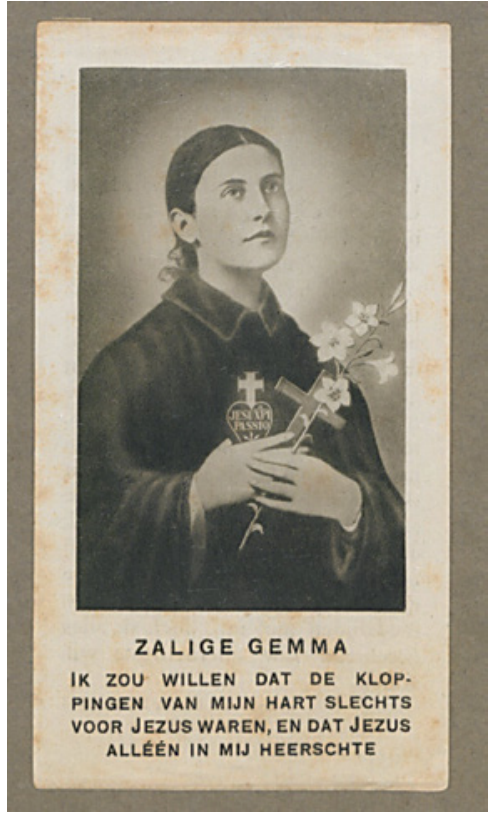

FIGURE 7.2

"Zalige Gemma"

ANTWERP, RUUSBROEC INSTITUTE

139 Luzzatto, Padre Pio, 49.

140 Pastoral Visit of the Holy Father Francis to Pietrelcina and to San Giovanni Rotondo, see n. 1. 


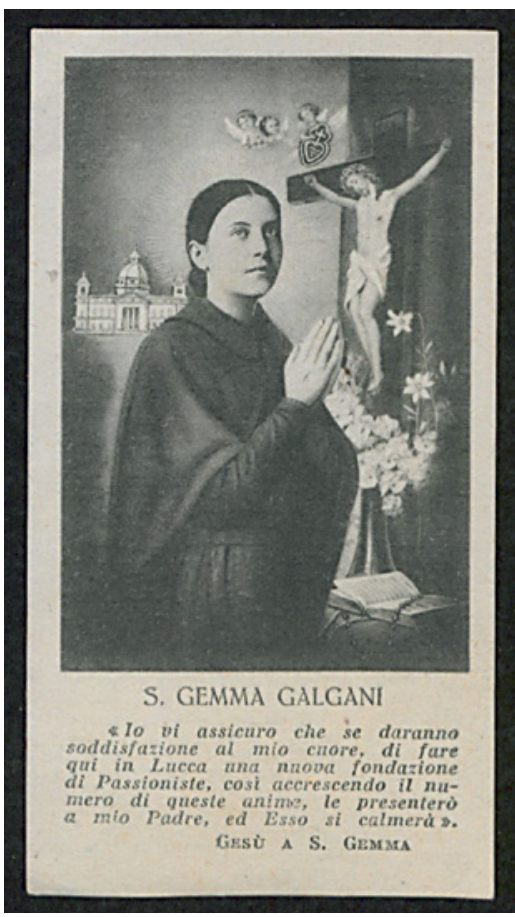

FIGURE 7.3

"S. Gemma Galgani" ANTWERP, PRIVATE COLLECTION LEONARDO ROSSI

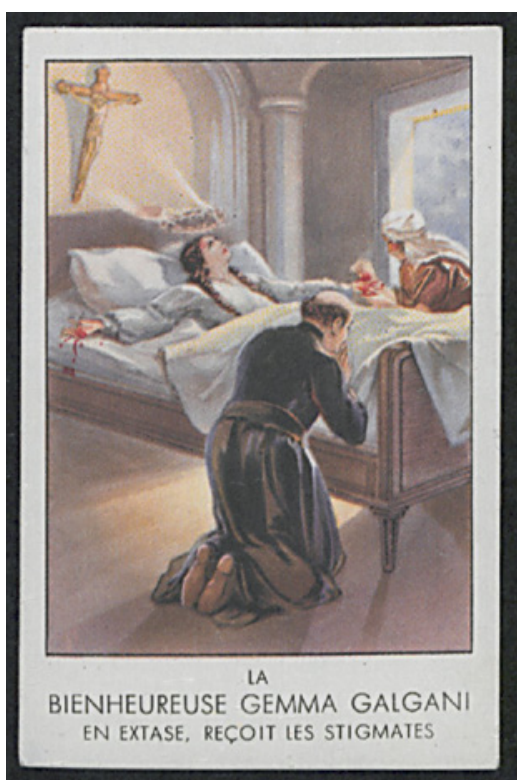

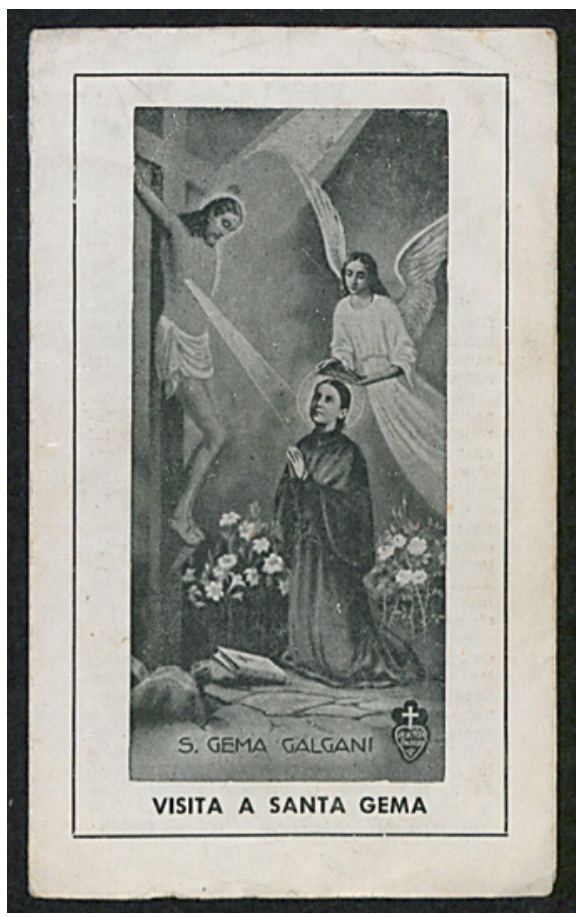

FIGURE 7.4

"Visita a Santa Gemma"

PRIVATE COLLECTION WILLIAM CHRISTIAN
FIGURE 7.5

"La Bienheureuse Gemma Galgani en extase, reçoit les stigmates"

ANTWERP, PRIVATE COLLECTION LEONARDO ROSSI 